窒素原子付加が $\Delta E_{\mathrm{N}}$ 老減少させ $\pi \rightarrow \pi^{*}$ 要移のレッドシフトに 站応する。これは赫必吸収スペクトル, NMR スペクトルの解积 と一致する。

\section{4 プロトンの酸甞原子付加と窒素原子付加の安定性の比㜞}

Mulliken ${ }^{14)}$ は結介土ネルギーの推起任を次式少的求的た。

$$
B=A S I /(1+S)
$$

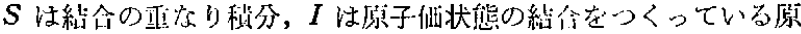

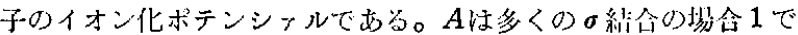
ある。

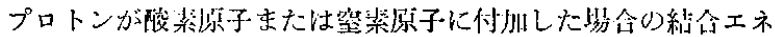
ルギーを武を伐って見䅡もって多る。イオン化ポテンシャルと

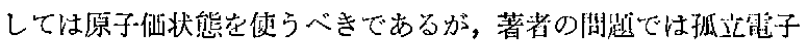
対にプロトンが付加したときの結合エネルギー㪯求めるのである が，むしろ孤立電子対のイオン化ポテンシァルをとるべきであ る。窒素原子，酸䋕原子のイオン化ポテンシャルとしては，そ机 ぞれピリシンメタノール15)の筑1 イオン化ボテンシャルを优朋 した。とくにピりシンをえらんだのは，オキシィミノ监の窒装原

14) R. S. Mulliken, J. Am. Chem. Soc. 72, 4493(1950),

15) I. Morrison, A. Nicholson, J. Chem. Phys, 20, 1021(1952).

16) H. Pritchard, H. Skinner, Chem. Revs. 55, 745(1955).
子は $s p^{2}$ 混成と考えられるからである。 $\mathrm{X}^{+}-\mathrm{H}$ 結合の重なり积

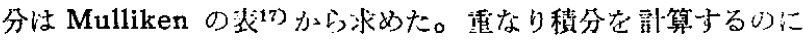

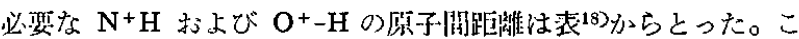
れらの数做を裴 6 に亦少。絬合エネルギーの葫算結果によれば，

$$
\begin{aligned}
& B_{\mathrm{N}^{+} \mathrm{H}}=4.2 \mathrm{eV} \\
& B_{\mathrm{O}^{+} \mathrm{H}}=2.8 \mathrm{eV}
\end{aligned}
$$

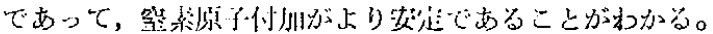

\begin{tabular}{|c|c|c|}
\hline イオン化水テンシェル & 絬合距雄(18) & 西なり漞分 \\
\hline$I_{\mathrm{H}}=13.60 \mathrm{eV}^{16)}$ & $l_{\mathrm{N}}{ }^{+} \mathrm{I}=1.034 \AA$ & $S_{\mathrm{N}^{+}-\mathrm{H}}=0.577$ \\
\hline $\begin{array}{l}I_{\mathrm{N}}=+9.23 \mathrm{eV}^{(5)} \\
I_{\mathrm{O}}=+10.85 \mathrm{eV}^{(5)}\end{array}$ & $l_{\mathrm{O}^{+} \mathrm{H}}=1.029 \AA$ & $S_{\mathrm{O}^{+}-\mathrm{H}}=0.297$ \\
\hline
\end{tabular}

表 6 イオン化ポテンシァル, $\mathrm{N}^{+} \mathrm{H}, \mathrm{O}^{+} \mathrm{H}$ 种會の

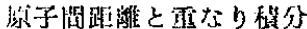

本研究に終始激尉御指導をいただきました当所主任破究是額田

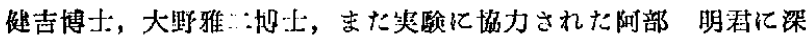
く感謝します。

17) R. S. Mulliken, C. A. Rieke, D. Orloff, H. Orloff, J. Chem. Phys. 17, 1248(1949).

18) "Tables of Interatomic Distances and Configuration in Molecules and Ions" London(1958)s. 7, s. 8 .

\title{
水溶液中の水銀滴の合一におよぼす界面活性物質の影警
}

(炤和 39 年 7 月 27 日受理)

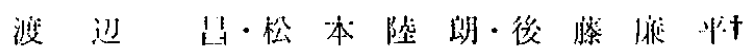

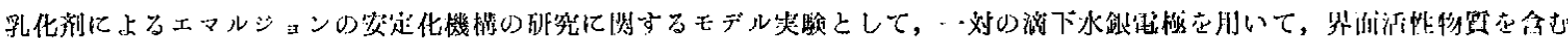

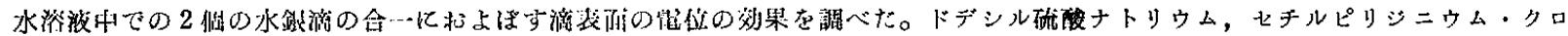
りド，ポリビニル・アルコールやエパン(ポリプロピレン・グリコールとポリエチレン・グリコールからなる非イオン性高分子界

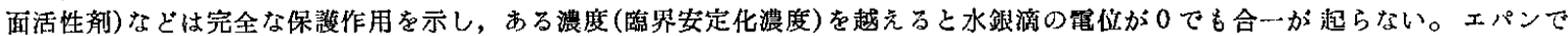

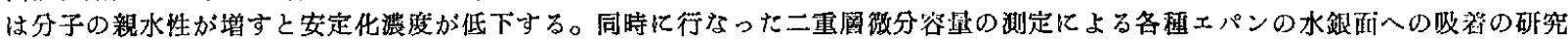
から，との安定化が主として界西活性物買の界面嗼形成によるものであるととが示された。

\section{1 緒 言}

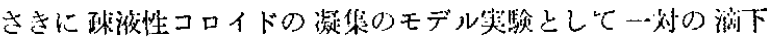

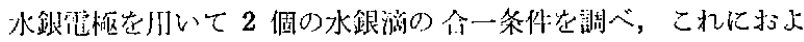

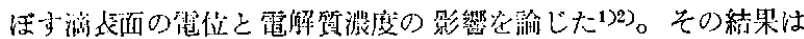
Verwey-Overbeek の凝集理諭とよく一致し，したがって電気

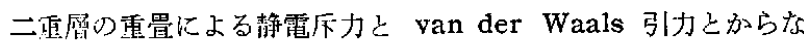
る柾液性コロイド精子阿の相互作㜾が，水銀滴のような巨視的な 系での粒子閉相互作用と本質的に同じであることが管証された。

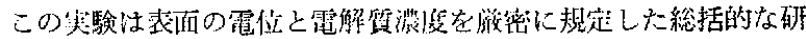
究として新しい意昧をもっている。

しかし，一般に液游䊀子の全一過程は凝集と狭洨の合一との二

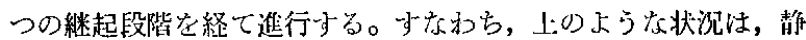
電布力が十分小さくて 2 粒子の装面が van der Waals 力の作 用圈内にまで近つきき得るがり必らず合一が起る場合である。し

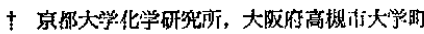

1) 後藤, 渡叕, 日化 84, 480(1963)

2) A. Watanabe, R. Gotoh, Kolloid-Z. 181, 36(1963).

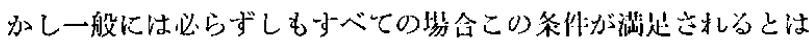
かきらない。たとえば，クェン陵ナトリウム浴液中での水銀滴の 合一笑験では，激废が高くなると合一の起\%電位領城がかえって 小さくなる。すなわちいらじるしい安定化が枇っている。これは

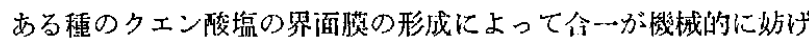
ら机るからであると推輪された1つ2)。

本報ではこのように凝策条件と合一条件が一致しない現象をさ らにくわしく系繶的に調べ，こ机が加光た界洏活性:物啠の性質，

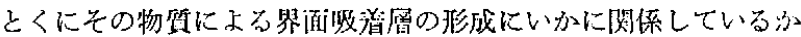

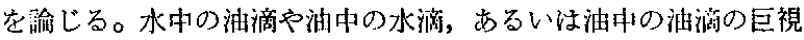
的な系を用いて液侗の今一条件におよほす界面活性郕の効果を調 ベた笑験は種々見られる3) 7。しかし，滴の表面の電位を明確に

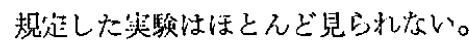

さて，このような合一過程め妨呫はコロイド現象に拈いてしば

3) E. G. Cockbain, T. S. McRoberts, J. Colloid Sci. 8, 440(1953)

4) T. Gillespie, E. K. Rideal, Trans, Faraday Soc. 52, 173(1956).

5) L. E. Nielsen, R. Wall, G. Adams, J. Colloid Sci. 13, 441(1958)

6) G. E. Charles, S. G. Mason, ibid. 15, 105(1960).

7) W. Albers, J. Th. G. Overbeek, ibid. 14, 501(1959). 
しば認められる。たとえげ，熱力学的㒫地尔ら少ると不可逆ゾル の最終平衡状態は界面秥の小さい目视仙沈殿の析出であ品が，笑

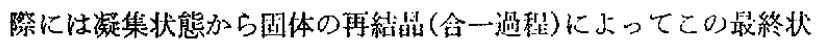
態に達する速度は非常に抢そい場合が多い8)。また, エマルジョ ンの解消による 2 相分崔(會一)にさきだって凝集によるクリーム

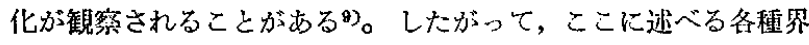

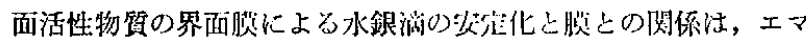

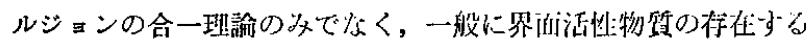

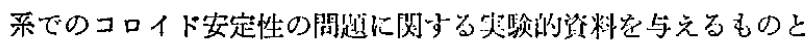
思动れる。

\section{2 実験}

\section{1 合一実験}

たとえば $0.1 \mathrm{~mol} / l$ 谓化力リウム水溶液りに先端を水平にま

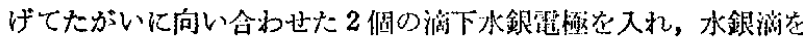
同時に流出生長させてたがいに摆触させる。外部からポテンシオ

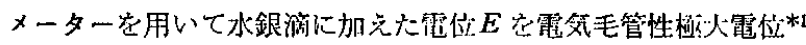

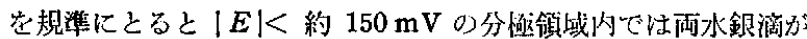
接触すると同時に令一が起り，|E|>約 $150 \mathrm{mV}$ では榈周り静 電斥力が大きいので合一が起らない。本研究では溶液中に種々の 界面活性物質を加えたときこの今一の需位領域がいかに変化する

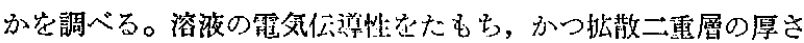

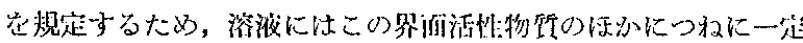

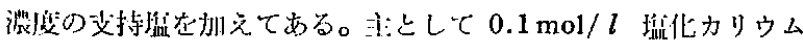

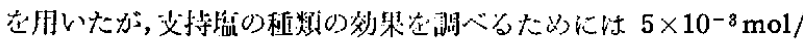

$l$ 硝酸ランタンセも用いた。

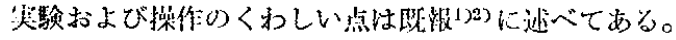

\section{2 二直層微分容量湖定}

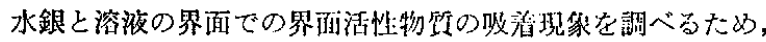
二重層微分容量を測定した ${ }^{10)}$ 。

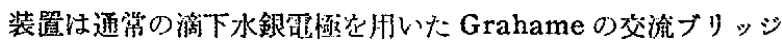

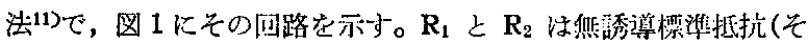
れぞれ $600 \Omega$ ), $\mathrm{C}_{\mathrm{s}}$ は可変然損失標準マイカ・コンデンサー(最小 0.0001 , 最大 $1.1111 \mu \mathrm{F}$ ), RS は可变無唀桴標㟆抵执（最小 0.1 , 最大 $100000 \Omega$ ) である。0に江低祘波 CR 発振器(横河 OV-CR-

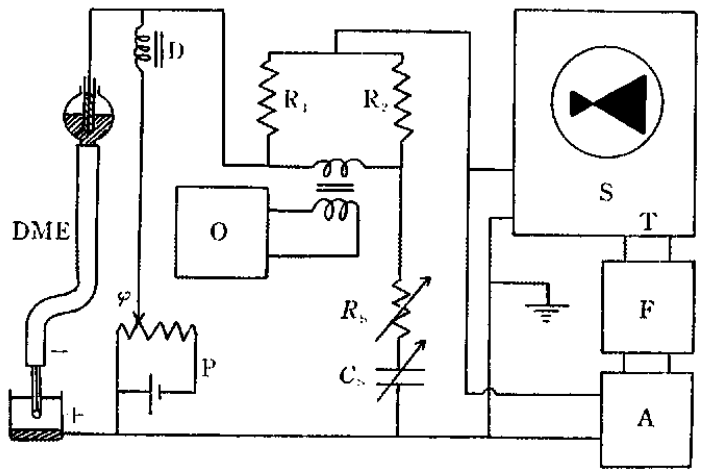

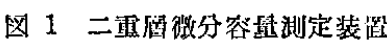

8) K. J. Mysels, "Indroduction to Colloid Chemistry", Inter science, New York(1959)p. 86.

9) P. Becher, “Emulsions" Reinhold, New York(1957)p. 138.

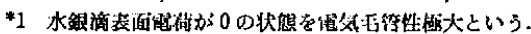

10）磼这，过，上田，電化 29，701(1961).

11) D. C. Grahame, J. Am. Chem. Soc. 63, 1207(1947); 88, 301(1946)
201)岩用い，これによって約 $10 \mathrm{mV}, 1000 \mathrm{cps}$ の交流岕ブリッ ジに玑兑た。ポテンシオメーターPはチョータ・コイルDを通し

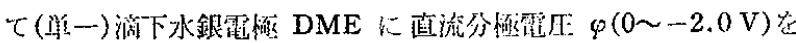

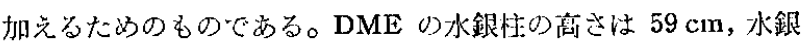

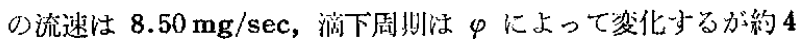
秒である。

いま，水銀滴の落下によって発生当るパルス電压岕增幅(A)し，

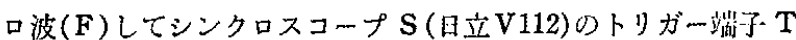

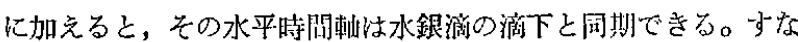
わち，乙の洔閌軸上の各点注水銀滴生長開始後の各㭙刻に対応し ている。乙の㭙刻安 $\tau(\mathrm{sec})$ と拈，そのときの DME のインピ 一ダンスの容量と抵抗成分(直列)に等しい值に Cs と Rs 苍諴 節すると，㭙刻てに秥いてブリッジの平衡が成立与る。したがっ てシンクロスコープのスクーリンには点てで収斂する図形があら われる(図 1 参照)。水銀の流速から時刻 $\tau$ での水鍶滴裴而程 $A$ が

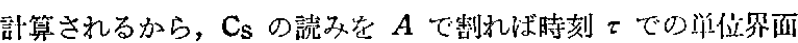

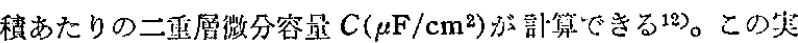
験では $\tau=0.2,0.4,0.8,1.0,2.0 \mathrm{sec}$ での $C$ 优を $\varphi$ の网数 として測定した。

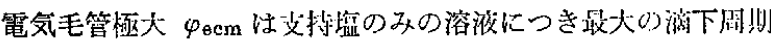

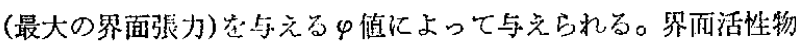

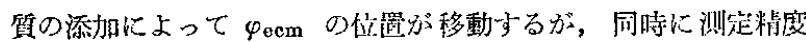

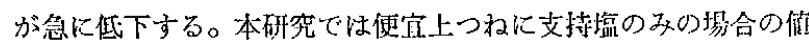

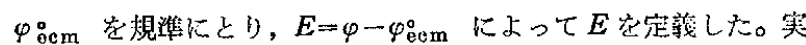

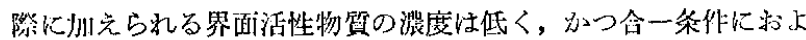

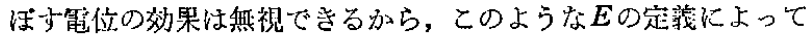
以下に述べる結諭が䍀りに陒いる心配はほとえぞない。

\section{3 試 料}

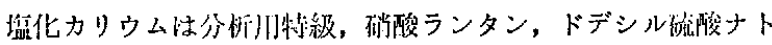
リウム(SDS)忙試望 1 級，セチルプリジニウム・クロリド(CPC)

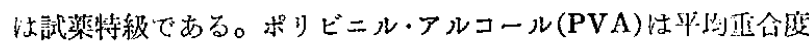
1380 , 残唒 $11.3 \mathrm{~mol} \%$ のもの䘮用いた。エパンは

\section{$\mathrm{CH}_{3}$ \\ $\mathrm{HO}\left(\mathrm{CH}_{2} \mathrm{CH}_{2} \mathrm{O}\right)_{a}\left(\stackrel{\mathrm{C}}{\mathrm{C}} \mathrm{H}-\mathrm{CH}_{2} \mathrm{O}\right)_{b}\left(\mathrm{CH}_{2} \mathrm{CH}_{2} \mathrm{O}\right)_{c} \mathrm{H}$}

で表わされるポリプロピレン・グリコール基 $(\mathrm{PO})$ を政水然，ポり エチレン・グリコール韭(EO)を親水基と当る非イオン惟滈分子

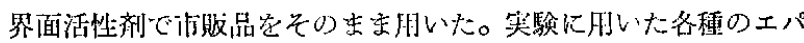
ンの性犋を哀 1 に示す。

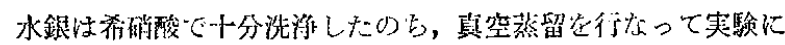

\begin{tabular}{|c|c|c|c|c|}
\hline エパン & $\begin{array}{r}\text { 表 } 1 \\
\text { 分子显 }\end{array}$ & PO基の & EO至の & HLI \\
\hline E710 & 2222 & 2000 & 222 & 2.52 \\
\hline E 720 & 2500 & 2000 & 500 & 5.57 \\
\hline E 740 & 3333 & 2000 & 1333 & 11.92 \\
\hline E 750 & 4000 & 2000 & 2000 & 16.82 \\
\hline E785 & 13333 & 2000 & 11333 & 86.91 \\
\hline E 410 & 1333 & 1200 & 133 & 3.95 \\
\hline E 420 & 1500 & 1200 & 300 & 5.20 \\
\hline E 450 & 2400 & 1200 & 1200 & 11.97 \\
\hline E 485 & 8000 & 1200 & 6800 & 53.95 \\
\hline
\end{tabular}

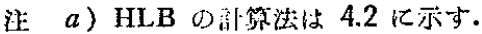


用いた。通常の蒸留水を硬質ガラス製の装置で蒸留した水(比伝 導度約 $10^{-8} \Omega^{-1} \cdot \mathrm{cm}^{-1}$ )をつね和いた。

\section{3 結果}

\section{1 合一電位領域}

支持盐が $0.1 \mathrm{~mol} / l$ 塭化カリウムのとき程々娍茷 $c(\mathrm{~mol} / l)$ の界面活性物質を加えたときの合一の臨界電位 $E_{+}$および $E_{-}$ $(\mathrm{mV})$ 亡 $\log c$ の関係の例を図 2 に示す。 $c$ が小さいと曲線仙横 刺に平行である。すなわち $0.1 \mathrm{~mol} / l$ 㦈化カリウムのみによっ て定市る命一の電位領域が見られる。しが，cが各界面活性物

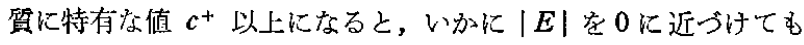
合一が起らない。すなわ各曲線注右側に閉じている。この搌度 $c^{+}$索䧗界安定化濃度 (critical stabilizing concentration) と呼 ぶことにしよう。図 2 によると $c^{+}$は CPC とエパンとでは約 100 倍位の違いがある。

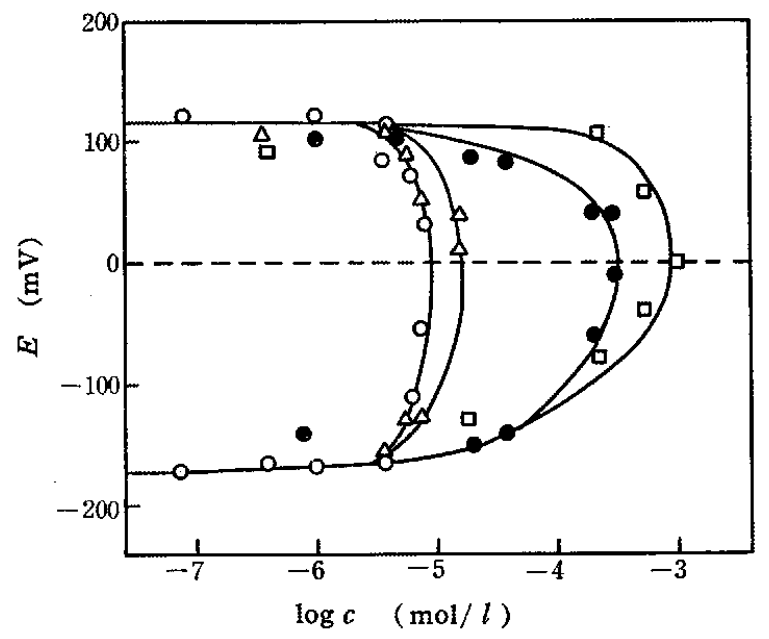

O: PVA 7, $\triangle$ : EPAN 785, O: SDS, $\square:$ CPC 支持塩: $0.1 \mathrm{~mol} / l$ 塩化力りウム

図 2 合一踟界電位と $\log$ 濃度の関係

そこで表 1 に示したように化学構造が规則的に造っている各種 のエパンについて $E_{ \pm}$対 $\log c$ 曲線を求めると洶 3 の結果が得ら れた。文持塩は $0.1 \mathrm{~mol} / l$ 嘷化カリウムである。 $c^{+}$注約 $10^{-3}$ $\sim 10^{-4} \mathrm{~mol} / l$ で, 明らかに親水性基と稙水性基との制合すなわ ち HLB が规則的に影響していることがわかる。

つぎに支持塩の効果孛調べるため, $5 \times 10^{-3} \mathrm{~mol} / l$ 硝酸ランタ ンを用いて实験を行なった。表 2 はその結果で，E740，E750， E785 に㧊いて $c^{+}$は支持瑥の種類に無関係なととがわかる。

このようにして界面活性物質による安定化注, 滴の電位と少溶 液の電解質の濃度や種類には支配されず, 界面活性物質そのもの の特性できまることがわかった。

表 2 踟界安定化濃度に抢上ぼす文持的の效果

\begin{tabular}{lcc} 
& \multicolumn{1}{c}{$(\mathrm{mol} / l)$} \\
\cline { 2 - 3 } エパン & $\begin{array}{c}0.1 \mathrm{~mol} / l \\
\mathrm{KCl}\end{array}$ & $\begin{array}{c}5 \times 10^{-3} \mathrm{~mol} / l \\
\mathrm{La}\left(\mathrm{NO}_{3}\right)_{3}\end{array}$ \\
E740 & $5.94 \times 10^{-5}$ & $6.0 \times 10^{-5}$ \\
E750 & $4.5 \times 10^{-5}$ & $6.0 \times 10^{-5}$ \\
E785 & $1.35 \times 10^{-5}$ & $1.25 \times 10^{-5}$
\end{tabular}

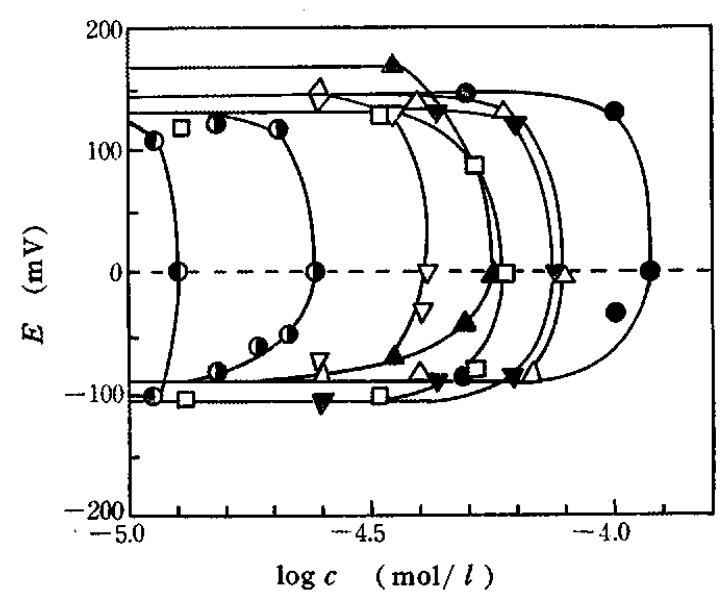

エパン

$\triangle: 720, \square: 740, \nabla: 750, \bigcirc: 785$

$410, \Delta: 420, \nabla: 450, \bigcirc: 485$

支持塩: $0.1 \mathrm{~mol} / l$ 塩化カリウム

図 3 合一畹界電位と $\log c$ との䦥係

\section{2 二言虽徽分容量}

上の合一実験の解彩の资料としてエパンE710，E740，E750，

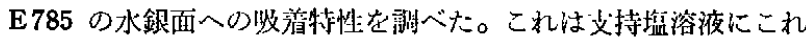
らの物質を添加したときの微分容星の低下少ら冰めることができ る10)13)。

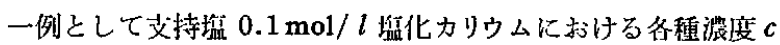
$(\mathrm{mol} / l)$ ) E740水溶液と接する水銀電㥛での二重層微分签量 $C$

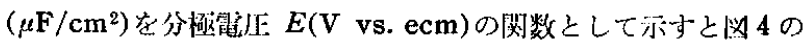

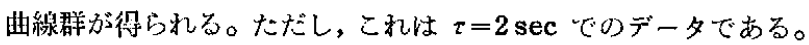
各曲線の形は界面活性物質に特有なもので， $E=0$ を中心にした

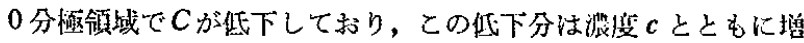
大寸る。 $E \leftrightharpoons-1.35 \mathrm{~V}$ に見られるピークは界酒活性物質の離着 過程に特有なもので, いわ以るテンサメトリーのピークに相当す る14) 18)。 $E>0$ の侧にもいま一つのピークが見られるはずであ

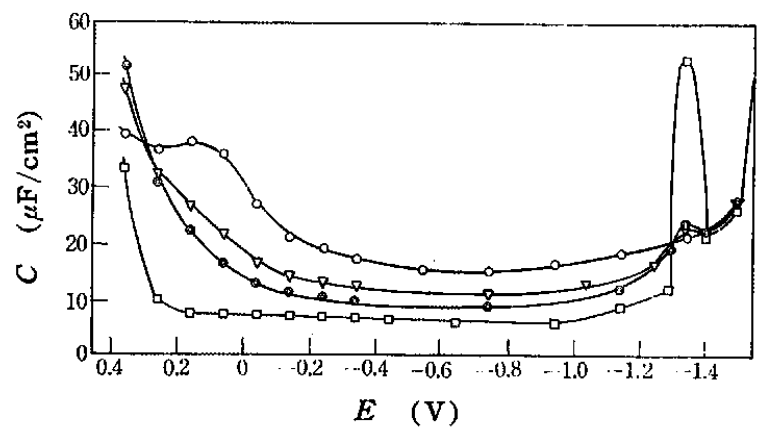

O: $0 \mathrm{~mol} / l, \square: 5.9 \times 10^{-5} \mathrm{~mol} / l$, $\nabla: 5.94 \times 10^{-8} \mathrm{~mol} / l$, (O): $7.92 \times 10^{-6} \mathrm{~mol} / \mathrm{l}$ エパン $\mathrm{E} 740$, 支持塩: $0.1 \mathrm{~mol} / l$ 塭化カリウム 図 4 微分容量と分極電压の関係

13) A. Watanabe, F. Tsuji, S. Ueda, Kolloid-Z. 191, 147(1963).

14) A. Frumkin, Z. Physik 35, 792(1692); Ergebn. 1, 235(1928).

15) D. C. Grahame, Chem. Revs. 41, 441(1947).

16) M. Proskurnin, A. Frumkin, Trans. Faraday Soc. 31, 110(1935),

17) R. Parsons, M. A. V. Devanathan, ibid. 48, 404(1953); 56, 373 (1954).

18) V. I. Melik-Gaikazjan, Zhur. Fiz. Khim. 28, 560(1952), 
るが，支持塩の $\mathrm{Cl}^{-}$イオンの吸着によってCが急湤に塪大寸す のでかくされてしまっている19)20)。

エパンの相対的吸着量は支持盐のみのとき $(c=0) の C-E$ 曲線 からの $C$ の低下量 $\Delta C \equiv C_{1}-C$ で与えられる。ここに $C_{1}$ は $C$ $=0$ のときの $C$ 值である。一例を図 5 亿示すと打り $\Delta C$ は $E$ の関数で, $E=0$ 付近に極大をるる $|E|$ が大きくなると $\Delta C=0$ になる。この現像は二重層電場が大きくなると，界面活性物質よ

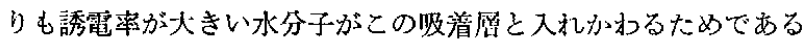

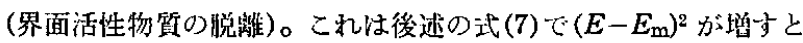
吸着自由エネルギーの紨刘倠が娍少することに机当する。
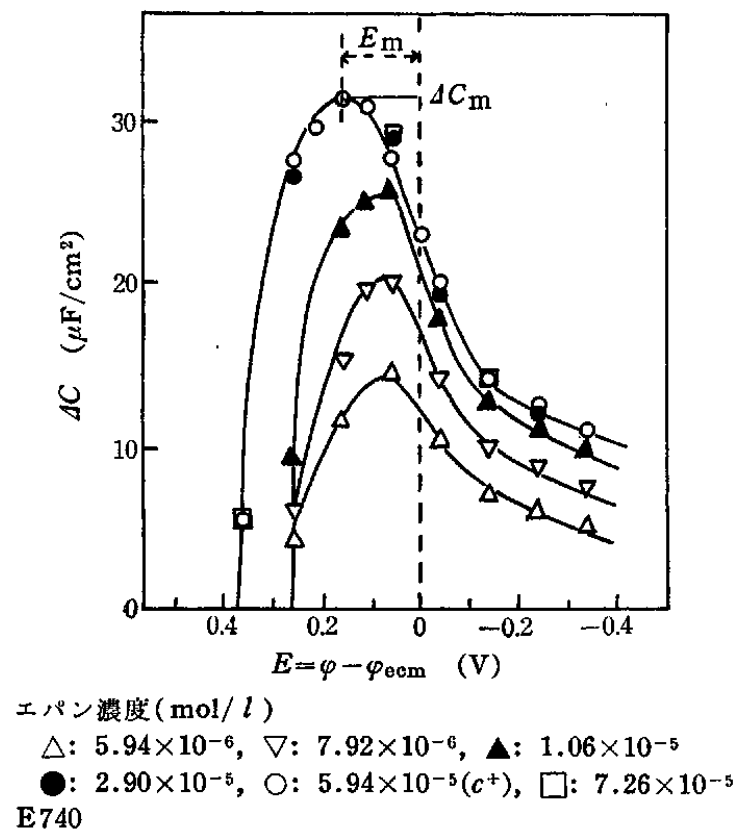

図 $5 \Delta C$ と $E$ の関係

$\Delta C$ の極大值 $\Delta C_{\mathrm{m}}$ を与える $E$ 值を $E_{\mathrm{m}}$ とすると，これは二 重層電場が0で吸着量が最大の状態をあらわすと考えられる。图 5 によるとエパン漫度 $c$ が增すと $E_{\mathrm{m}}$ 恃陽分極 $(E>0) 0$ 方向に ずれ，つ称に $E_{\mathrm{m}}>0$ である。一般に $c$ が嬶ずと $\Delta C_{\mathrm{m}}$ が大きく なるが, $c=5.94 \times 10^{-5} \mathrm{~mol} / l$ を越えるともはや $4 C-E$ 曲緗は $c$ に依存せず, $E_{\mathrm{m}}=0.16 \mathrm{~V}, \Delta C_{\mathrm{m}}=30.55 \mu \mathrm{F} / \mathrm{cm}^{2}$ という一这値 をたもつ。このような举動は他のエパンでも浑められ，しかも

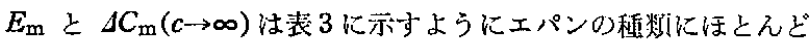
無関係のようである。

他の非イオン性界面活性斉の水銀而への吸痖の研究によえと， 吸着過程の時定数が測䇥の時間尺度と同程度になることがあり， とくに低濃度では時喵效果がいちじるしい21222)。そして一般に眭

表 $3 c \rightarrow \infty$ ての $E_{\mathrm{m}}$ と $\Delta C_{\mathrm{m}}$

$\begin{array}{lcc}\text { エパン } & E_{\mathrm{m}}(\mathrm{V}) & \Delta C_{\mathrm{m}}\left(\mu \mathrm{F} / \mathrm{cm}^{2}\right) \\ \text { E710 } & 0.16 & 30.55 \\ \text { E740 } & 0.16 & 30.55 \\ \text { E750 } & 0.16 & 30.19 \\ \text { E785 } & 0.16 & 28.93\end{array}$

19) B. Breyer, S. Hacobian, Australian J. Chem. 9, 7(1956).

20) A. Watanabe, F. Tsuji, S. Ueda, Kolloid-Z. 193, 39(1963).

21）上田, 渡辺, 辻, 電化 30, 657(1962); 31, 32(1963).

22) A. Watanabe, F. Tsuji, S. Ueda, Kolloid-Z. 198, 87(1664).
刻てでの $\Delta C$ 泩次式で与えられることが笑験的に示された。

$$
\Delta C=\Delta C_{\infty} \exp \left(-\frac{T_{\mathrm{m}}}{\tau}\right)
$$

または

$$
\log \Delta C=\log \Delta C_{\infty}-\frac{T_{\mathrm{m}}}{2.303 \tau}
$$

ここに $A C_{\infty}$ は $\tau \rightarrow \infty$ で吸䄑平衡に達したときの $A C$ 优であり， $T_{\mathrm{m}}$ は四着過程の時定数である。エパン E740 について $\tau=0.2$, $0.4,0.8,1.0,2.0 \mathrm{sec}$ で $\Delta C$ 它求め $\log A C$ 它 $1 / \tau$ に対L

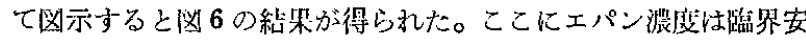
足化浱度 $c^{+}=5.94 \times 10^{-5} \mathrm{~mol} / l$ で, 支持塩は $0.1 \mathrm{~mol} / l$ 掹化 カリウムである。図から判断してこの条件では $T_{\mathrm{m}}$ は大きくて も数 $\mathrm{msec}$ の程展である。

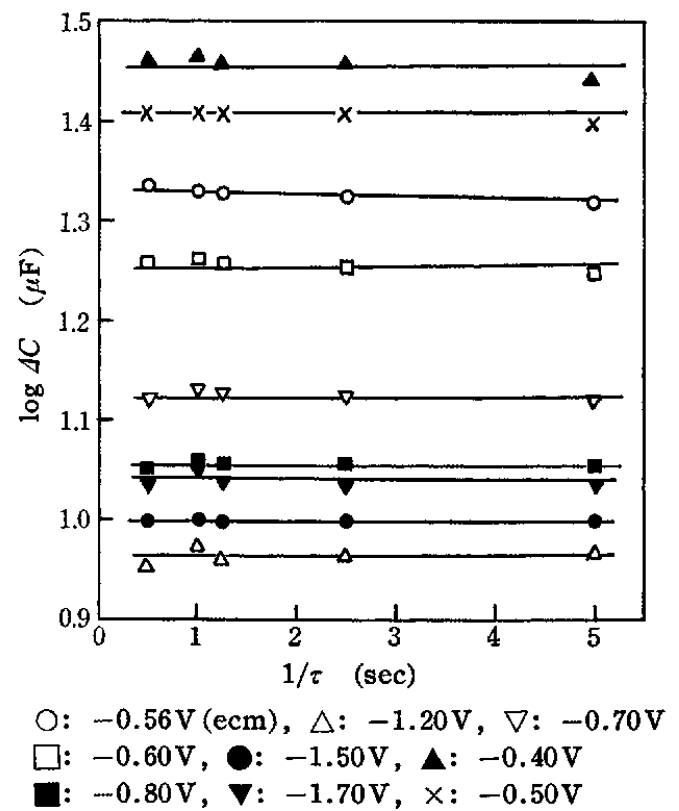

図 6 微分容量の経時変化

今心一の䍒驗において水銀滴の生長開始後，2滴の装面が接触与 るまでの時䦌は 0.02 秒の程座である。このような短封蔺での微 分容最Cの测定はいまのところ不可能である。しかし，上の経時

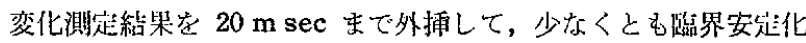

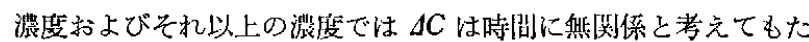
いした誤りはないと思われる。したがって以下の議諭においては $\tau=2.0 \mathrm{sec}$ での微分容量のデータを用いて諭議安進めることにす る。

\section{4 考察}

\section{1 吸着特性}

二重層微分容鼠の测定絬果から見て，界画活性物㔖の吸着愿が 水銀滴の合一を妙げていることは明ら少である。そこで, 末ず, 吸淡特性を棆じることにする。

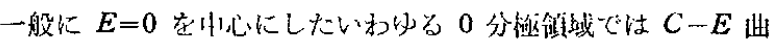

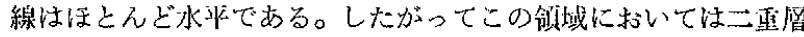
秥分容量 $K \equiv \sigma / E$ 恃微分容丝 $C \equiv \mathrm{d} \sigma / \mathrm{d} E$ にほとんぞ等しい。こ

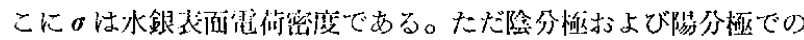
故看ピーク付近およびそれより外侧の分椣領域でのみ $K$ とと 
の相異がいちじるしい21)。含一の起るのは $\mid E K<0.15 \mathrm{~V}$ だから，

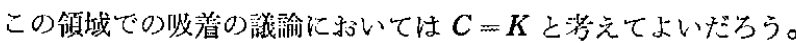

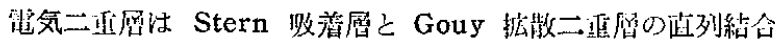

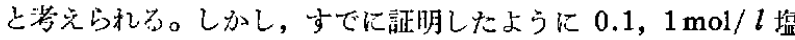

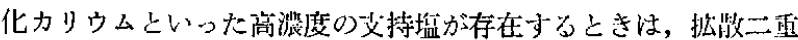

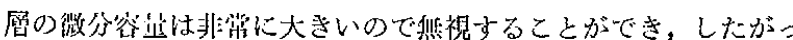

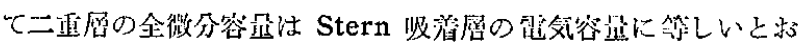
くことがナ゙きる18)。

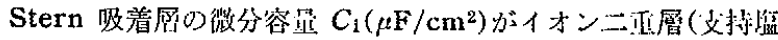

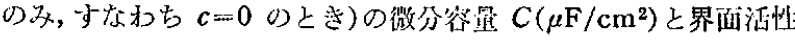

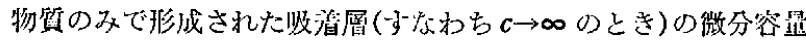

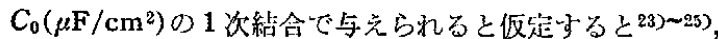

$$
C=C_{\mathrm{i}}(1-\theta)+C_{0} \theta, \quad 0 \leqq \theta \leqq 1
$$

ここに $\theta$ は被得の制合(coverage)であり，Langmuir-Stern 型

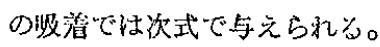

$$
\theta=\frac{b N}{1+b N}
$$

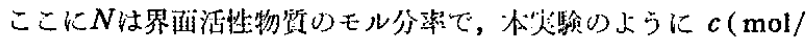

l)劝-分小さいとつぎの上うにおくことができる。

$$
c=55.6 \mathrm{~N}
$$

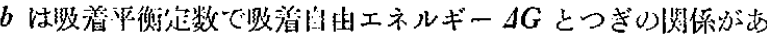
\%o

$$
\Delta G=-\boldsymbol{R} T \ln b
$$

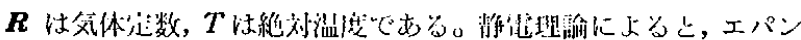

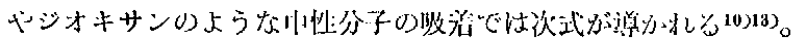

$$
\Delta G=a\left(E-E_{\mathrm{m}}\right)^{2}+\Delta G_{\mathrm{ch}}
$$

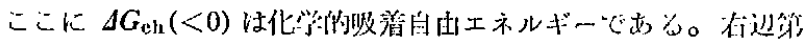

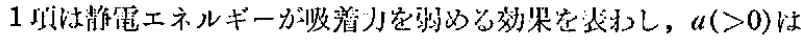

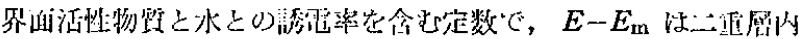

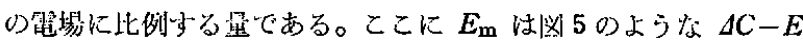
旧線の極大を与える電位である13)。

$$
\text { 式(3)において }
$$

$$
\Delta C \equiv C_{\mathrm{i}}-C, \quad \Delta C_{0} \equiv C_{\mathrm{i}}-C_{0}
$$

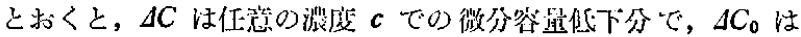
$c \rightarrow \infty$ (すなわち $\theta=1$, 完全被曐)での $A C$ 值である。これを式 (4)に代入し，式(5)を用いると，

$$
\frac{1}{\Delta C}=-\frac{1}{\Delta C_{0}}\left(1+-\frac{55.6}{b} \cdot \frac{1}{c}\right)
$$

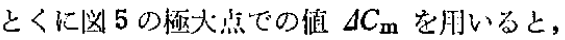

$$
\frac{1}{\Delta C_{\mathrm{m}}}=\frac{1}{\Delta C_{0 \mathrm{~m}}}\left(1+\frac{55.6}{b} \cdot \frac{1}{c}\right)
$$

ここに

$$
\Delta G_{\mathrm{ch}}=-\boldsymbol{R} T \ln b_{\mathrm{m}}
$$

である。

図 7 注エパン E710, 740,750,785 についとの $1 / \Delta C_{\mathrm{m}}-1 / c$ 曲線である。明以加に $1 / c$ が火きい領域(低泿度)では直線圆係 が成立し，Langmuir 㤠の败着が起っていることを示している。

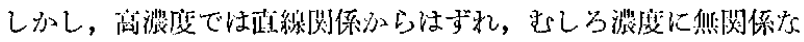
横帆に平行な直線に移っている。このような㫜象注他の非イオン

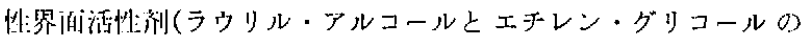

23) W. Lorenz, F. Möckel, Z. Elektrochem. 60, 507(1956).

24) T. Berzins, P. Delahay, J. physic. Chem. 58, 906(1955).

25) M. Senda, I. Tachi, Rev. Polarography 10, 79(1962).
其苜合物)でも見られている26)。おとらく界画での coverage が

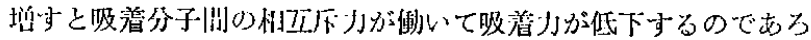
う。

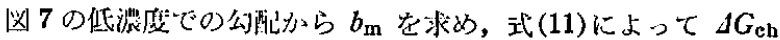
安计算与ると图 8 に亦与ように分子中の竌水基 EO の制合 $x$ と

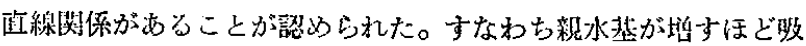

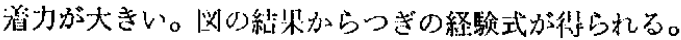

$$
\Delta G_{\mathrm{ch}}=-7.77-x \quad \mathrm{kcal} / \mathrm{mol}
$$

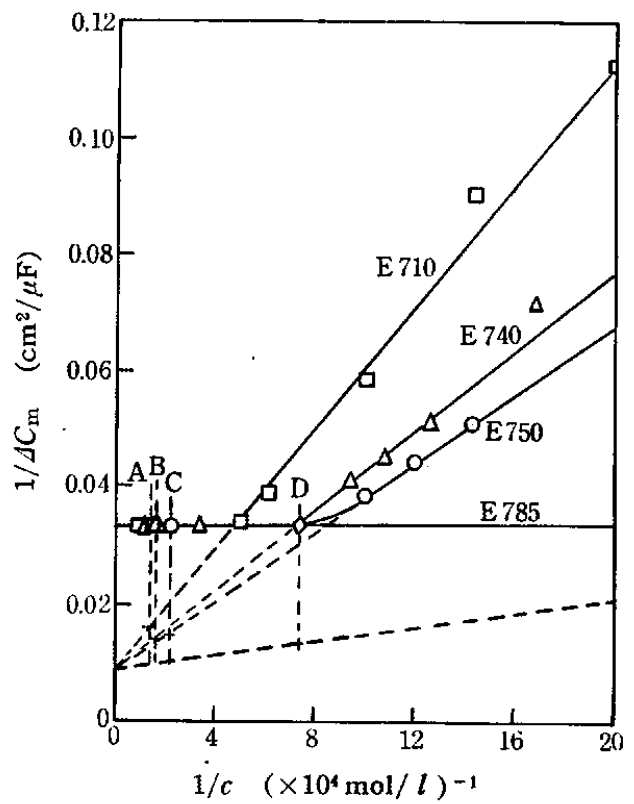

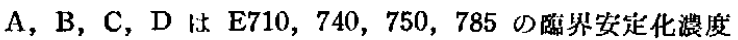
図 $7 \quad 1 / \Delta C_{m}$ \& $1 / c$ の関係

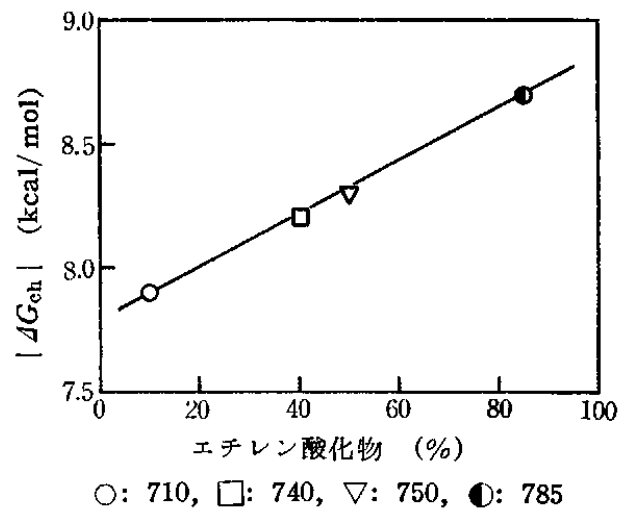

図 8 忣著自由エネルギ一と親水性の関係

\subsection{HL B との関係}

水銀滴の令一资験は $\mathrm{O} / \mathrm{W}$ 型エマルジョンの今一のモデルと考 えることができる。この埸命，合一が起るためには二つの㵜の表

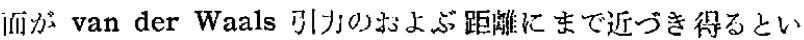

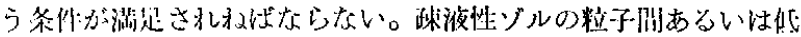

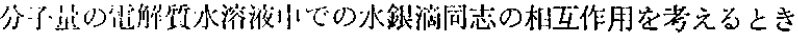

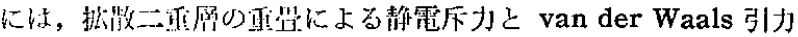

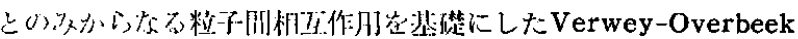

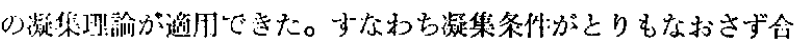

26）上田，巍辽，辻，鼠化 30，582(1962) 
一条件であった1)2》。しかし，乳化剂によって安定化されたエマル

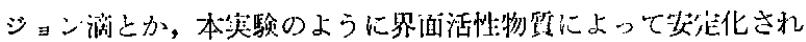

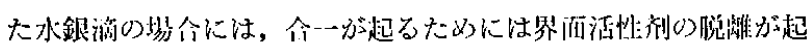

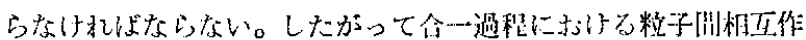

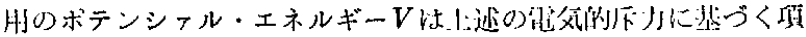

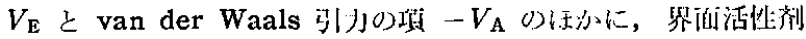

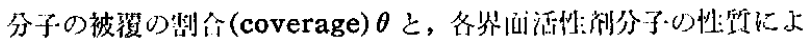
ってきまる $1 \mathrm{~mol}$ あたりの脱踓向山エネルギー炶 乞の代数和で与えられる。

$$
V=V_{\mathrm{E}}-V_{\mathrm{A}}+\theta v_{\mathrm{A}}
$$

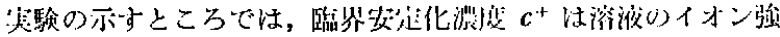

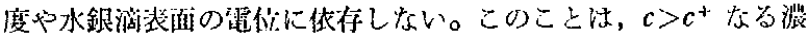

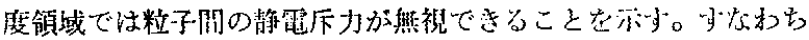
$\left|V_{\mathrm{E}}\right| \ll\left|V_{\mathrm{A}}+\theta v_{\mathrm{A}}\right|$ ¿して

$$
V=-V_{\mathrm{A}}+\theta v_{\mathrm{A}}
$$

Albers と Overbeek ${ }^{27}$ )が W/O(ベンゼン)筡エマルションの

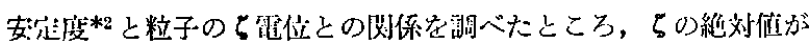

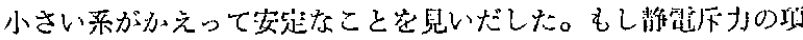

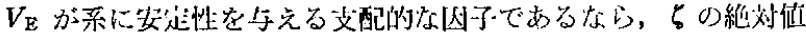

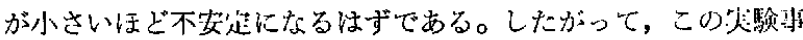

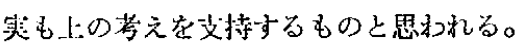

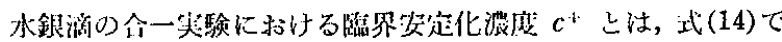

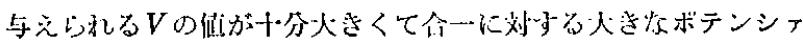

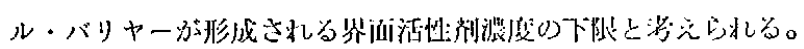
このとき $\theta=\theta^{+}, V=V^{+}, c=c^{+}$と打くと

$$
-V_{\mathrm{A}}+\theta^{+} v_{\mathrm{A}}=V^{+} \gg \boldsymbol{R T}
$$

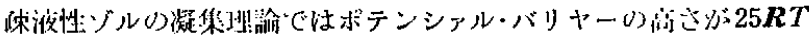

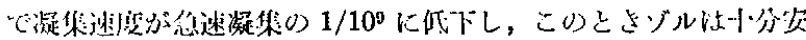

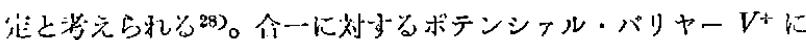

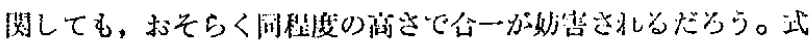
(4), (5), (15) \%ら

$$
\frac{v_{\mathrm{A}}}{V^{+}+V_{\mathrm{A}}}=\frac{1}{\theta^{+}}=1+\frac{55.6}{b} \cdot \frac{1}{c^{+}}
$$

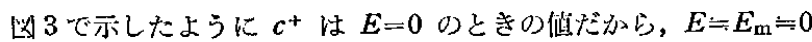

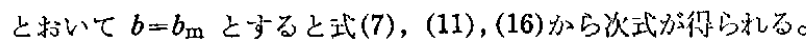

$$
\log c^{+}=\log 55.6-\log \left(\frac{v_{\mathrm{A}}}{V^{+}+V_{\mathrm{A}}}-1\right)+\frac{\Delta G_{\mathrm{cl}}}{2.303 R T}
$$

したがって，もし $v_{\mathrm{A}}$ が一资なら $\log c^{+}$と $\Delta G_{\mathrm{ch}}$ は公配 $1 /(2.303$ $\boldsymbol{R} T$ )の正維刚係をもつはずである。エパン E710, 720,740,785 については単 9 に示よように, E785 を除くと

$$
\log c^{+}=-0.41+\frac{\Delta G_{\mathrm{ch}}}{2.303 R T}
$$

で与えられる直線関係がほほ成立している。

一般に $S G(<0)$ の絶対值は界泊活性物質エパンの親水性が增 与と增大寸る(式(12)参照)。したがって脱路エネルギー $v_{\mathrm{A}}$ も漞 水性とともに增大寸る。したがって分子の親水性が堵一ほど式

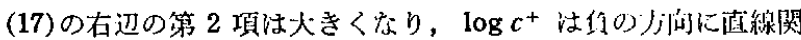

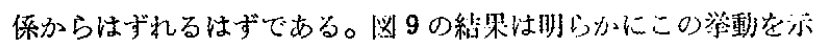
している。もっと一般的にいって，分子け HLB が大きいぼ゙

27) W, Albers, J. Th. G. Overbeek. J. Colloid Sci. 14, 501, 510(1959); 15, 480(1960)

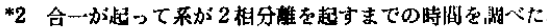

28) E. J. W. Verwey, J. Th. G. Overbeek, "Theory of the Stability of Lyophobic Colloid" Elsevier, Amsterdam (1948) p. 169.

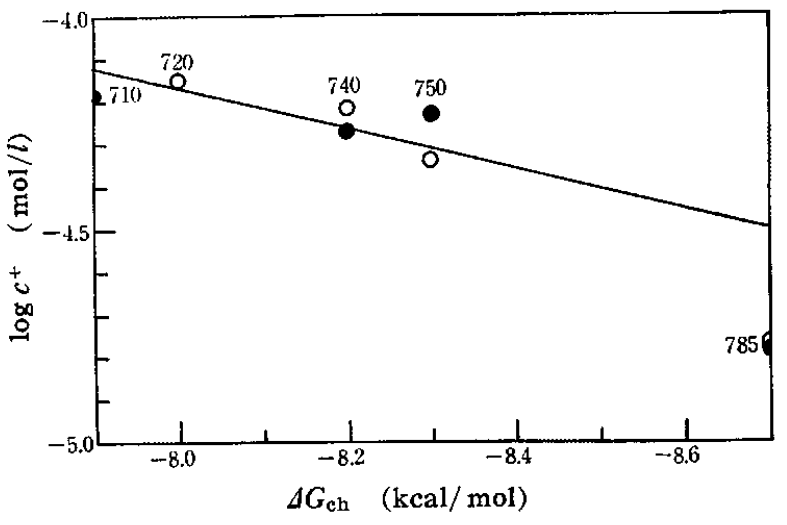

\begin{tabular}{|c|c|c|c|}
\hline E 720 & 0.1 & (O): E710 & 5 \\
\hline E 740 & 0.1 & $\Theta:$ E740 & 5 \\
\hline E750 & 0.1 & ○: E750 & 5 \\
\hline E785 & 0.1 & ○: E780 & 5 \\
\hline E 420 & 0.1 & & \\
\hline E 450 & 0.1 & & \\
\hline (1): E 480 & 0.1 & & \\
\hline
\end{tabular}

O: 芰持塩 $0.1 \mathrm{~mol} / / \mathrm{KCl}$

：支持塩 $5 \times 10^{-3} \mathrm{~mol} / l \mathrm{La}\left(\mathrm{NO}_{3}\right)_{3}$

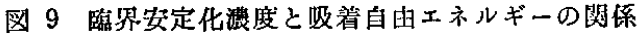

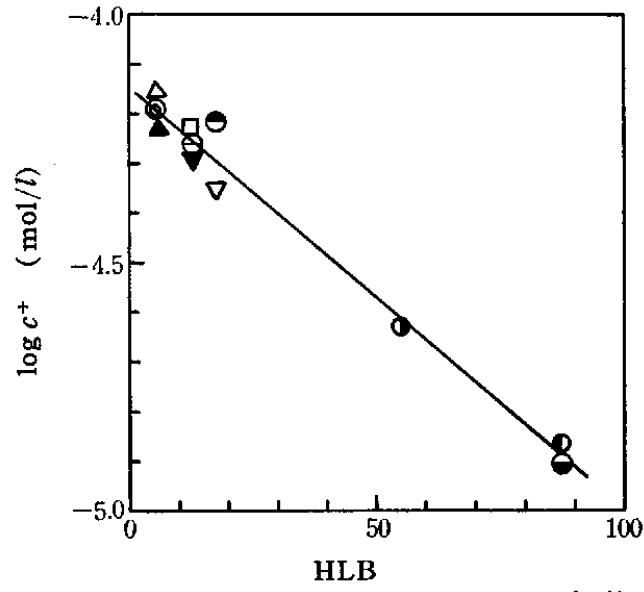

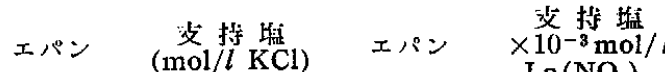

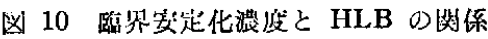

$\log c^{+}$は小さいことが尔想される。事実图 10 に亦すように本这 狳に得られたすべてのエパンについての結架では, $\log c^{+}$と HLB は直線性を示している。ここに HLB は慗 1 に录した值で, Davies の式29)

HLB $=\Sigma$ (EOのGroup 数 $)-\Sigma($ POのGroup 数 $)+7$

によって求めた值である。このように訫算した HLB 值はもるる

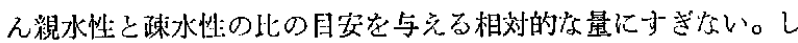
たがってこれをまったく满诰を異にする SDSや CPCなどにつ いてのデータと比輅することは無意味と思われる。

終りに，ポリビニル・アルコール性大日本紡續圾越工埁に扎い て合成されたものである。またエパンは第一工策製薬の製品であ る。これらを提供された闻社に曆く感謝の意を表する。

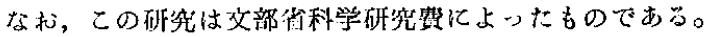

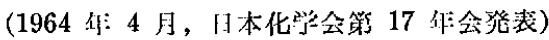

29) J. T. Davies, Proc. 2nd Intern Congr. Surface Activity, London (1957)1, p. 426. 